\title{
SISTEM MONITORING PERKEMBANGAN ANAK BERBASIS DENVER DEVELOPMENT SCREENING TEST (DDST / DENVER II)
}

\author{
Rahadian Kurniawan $^{1}$, Izzati Muhimmah ${ }^{2}$, Helmi Roichatul Jannah ${ }^{3}$ \\ Jurusan Teknik Informatika, Fakultas Teknologi Industri, Universitas Islam Indonesia, ${ }^{1,2,3)}$ \\ Jl.Kaliurang Km.14,5, Sleman, Yogyakarta, 55584 \\ E-Mail :rahadian.kurniawan@uii.ac.id ${ }^{1}$,Izzati.Muhimmah@uii.ac.id ${ }^{2}$
}

\begin{abstract}
Even compared to the same age, the growth of every child is way different. The parent has to do an assessment against their child so that they could understand about how and how much the child grows. One of assessment methods that could be used is a Denver Development Screening Test (DDST) or usually called Denver II. Denver II contains 4 sectors which tested against children, those: Social Personal, Soft Motoric, Language, and Hard Motoric. An assessment using the Denver II could be conducted not only in the clinic or hospital but also in patient home using a help from a psychologist or other health workers as a tester. A DDST application based on Android was designed to facilitate a tester doing an assessment out of the clinic or hospital. Data of an assessment managed over a decision support system that build alongside a DDST application. Application was constructed based on instrument of Denver II, which are question form and manual test. Application testing conducted in two ways: usability testing, which could show whether an application could run well as the need lists; and validation testing using Single Decision Threshold have sensitivity amount of 100\%, specificity amount of $87.5 \%$ and value apps performance amount of $90 \%$. Using Coefficient Cohen's Kappa has an accuracy amount of 0.74 (Strong).
\end{abstract}

Keywords : Growth, Assessment, Denver II, Android.

\section{PENDAHULUAN}

Denver Developmental Screening Test (DDST) : Denver II adalah sebuah metode asesmen yang di gunakan untuk menilai perkembangan anak dengan umur kurang dari 6 tahun. Tes ini dikembangkan oleh William K. Frankenburg dan J.B. Dodds pada tahun 1967 (William K. Frankenburg \& Dodds, 1967). DDST merefleksikan persentase kelompok anak usia tertentu yang dapat menampilkan tugas perkembangan tertentu, untuk kemudian dibandingkan dengan perkembangan anak yang seusia. DDST menilai 4 sektor perkembangan, yaitu

1. Personal Sosial (penyesuain diri di masyarakat dan kebutuhan pribadi).

2. Motorik Halus - Adaptif (koordinasi mata - tangan, kemampuan memainkan dan menggunakan benda - benda kecil, serta pemecahan masalah).

3. Bahasa (mendengar, mengerti dan menggunakan bahasa).
4. Motorik Kasar, yaitu duduk, berjalan, dan melakukan gerakan umum otot besar lainnya.

Dalam perkembangannya DDST mengalami beberapa kali revisi. Revisi terakhir adalah Denver II, yang merupakan hasil revisi dan standarisasi dari DDST dan DDST-R (Resived Denver Developmental Screening Test) (W. K. Frankenburg, Dodds, Archer, Shapiro, \& Bresnick, 1992). Perbedaan Denver II dengan skrining terdahulu terletak pada item-item tes, bentuk, interpretasi dan rujukan (Nugroho, 2008).

Tes DDST dilakukan oleh orang yang memiliki kompetensi tentang perkembangan anak. Dalam melakukan tes, pemeriksa menggunakan dua instrumen, yaitu: form kertas yang berisi item tes, dan manual pelaksanaannya. Jika salah satu instrumen tidak ada, maka tes tidak dapat dilakukan. Selain itu, berdasarkan hasil wawancara dengan seorang Psikolog Anak dari Universitas Islam Indonesia, tes DDST tidak 
hanya dapat dilakukan di klinik maupun rumah sakit, tetapi dapat juga dilakukan di rumah pasien. Sehingga, form kertas yang digunakan rentan hilang, dan tertinggal. Perbedaan hasil asesmen sering kali terjadi terutama bagi pemeriksa yang kurang pengalaman. Perbedaan tersebut kerap kali terjadi karena form berbasis kertas menuntut pemeriksa untuk hafal rumus yang dapat menyebabkan perbedaan sudut pandang ketika menentukan kondisi anak dinyatakan lulus, gagal, maupun tidak dapat diuji. Selain itu, hasil penilaian berbasis kertas sulit untuk dilakukan proses analisis mengenai kemajuan perkembangan anak berdasarkan hasil proses asesmen rutin.

Berdasarkan masalah tersebut, maka dibutuhkan sebuah teknologi yang mampu membantu pemeriksa untuk mengelola tes maupun hasil asesmen anak. Pada penelitian ini dibangun aplikasi DDST berbasis mobile (Android) yang digunakan oleh pemeriksa untuk melakukan tes dimanapun dan kapanpun. Sebagai media pengelolaan hasil tes pada anak, aplikasi berbasis web dibangun untuk mengelola data asesmen oleh administrasi.

\section{LANDASAN TEORI}

\subsection{Tinjauan Pustaka}

Beberapa penelitian berbantu komputer telah dilakukan sebelumnya untuk membantu para pemeriksa dalam melakukan tes Denver, antara lain: penelitian yang dilakukan oleh (Ivantoni \& Muhimmah, 2015) telah berhasil membangun aplikasi berbasis web yang dapat digunakan oleh pemeriksa untuk melakukan tes Denver. Selanjutnya, (Gumiri, Puspitaningrum, \& Ernawati, 2015) membangun aplikasi sistem pakar dengan mengacu DDST berbasis desktop yang dapat membantu pakar dalam mendeteksi status perkembangan anak dengan menerapkan algoritma naïve bayes classification. Aplikasi sistem pakar dengan mengacu DDST juga dilakukan penelitian (Laksana \& Sriyulia, 2016) menggunakan metode Certainty Factor. Penelitian (Widodo, Kusrini, \& Boedijanto, 2014) mengembangkan multimedia dalam sistem pakar yang bertujuan untuk membantu orang tua untuk melakukan skrining terhadap anaknya dengan lebih baik dan akurat menggunakan metode forward chaining.

Meskipun beberapa penelitian terdahulu menunjukkan adanya manfaat yang baik, namun beberapa penelitian tersebut belum mengatasi beberapa masalah yang akan diselesaikan pada penelitian ini, antara lain: menurut hasil wawancara terhadap dua orang Psikolog, Form kertas masih dipilih oleh kebanyakan pemeriksa daripada menggunakan komputer karena dianggap lebih mudah di operasikan jika pemeriksa harus berpindah - pindah lokasi. Selain itu, penggunaan aplikasi berbasis komputer maupun laptop membatasi interaksi pemeriksa dengan anak ketika proses asesmen. Selanjutnya, pada penelitian terdahulu belum di lengkapi fitur gambar kondisi anak dinyatakan lulus pada tiap soal. Pada banyak kasus masih terjadi perbedaan sudut pandang mengenai status lulus tidaknya anak terhadap soal yang diberikan terutama bagi pemeriksa yang belum berpengalaman.

Penelitian yang dilakukan mengusulkan sebuah aplikasi berbasis mobile (Android) yang dapat membantu pemeriksa untuk dapat lebih berinteraksi dengan anak saat proses asesmen. Selain itu, pada apalikasi ini dilengkapi dengan gambar kondisi lulus pada masing-masing soal, sehingga membantu pemeriksa yang belum berpengalaman untuk menentukan status anak pada tiap soal. Selanjutnya, aplikasi berbasis web dibangun untuk menyimpan dan mengelola hasil asesmen pada masing-masing anak. Pada aplikasi berbasis web ini, selain digunakan oleh administrator, pemeriksa juga dapat masuk untuk memonitor perkembangan masing-masing anak.

\subsection{Dasar Teori}

Denver Development Screening Test (DDST): Denver II digunakan untuk membantu dalam identifikasi awal perkembangan terhadap masalah dan penundaan pada anak - anak pra-sekolah, yaitu usia kurang dari 6 tahun. Menurut studi 
yang dilakukan oleh The Public Health Agency of Canada, DDST adalah metode tes yang paling banyak digunakan untuk skrining masalah perkembangan anak (Nugroho, 2008). Meskipun dapat dilakukan pada anak dengan usia kurang dari 6 tahun, namun idealnya Denver II dilakukan oleh anak usia 3 atau 4 bulan, kemudian saat usia 10 bulan dan 3 tahun. Hal ini dilakukan untuk memudahkan evaluasi perkembangan anak (Pilllitteri, 2010).

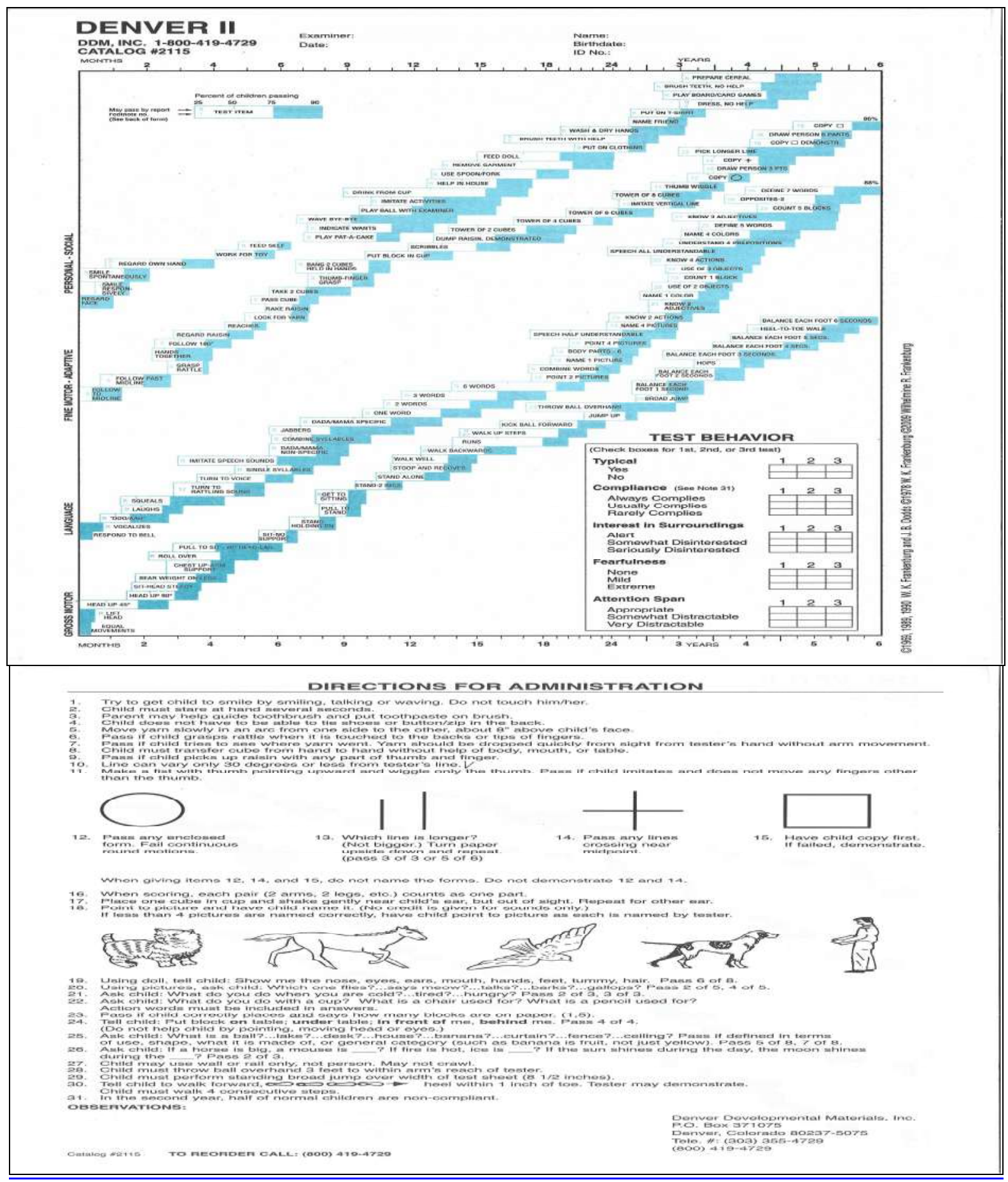

Gambar 1. Halaman depan (atas) dan belakang (bawah) form DDST.

(Sumber: $h$ ttp://denverii.com/denver-ii-test-form-english)

Gambar 1 menunjukkan gambar form berbasis kertas dari form DDST. Pada halaman depan form DDST terdapat 125 item yang dibagi dalam 4 sektor yaitu 
Personal Sosial, Motorik Halus - Adaptif, Bahasa dan Motorik Kasar sesuai usia setiap tahap perkembangan. Pada halaman belakang form DDST terdapat petunjuk pelaksaan tes untuk beberapa item.

\section{METODOLOGI PENELITIAN}

\subsection{Pengumpulan Data}

Pengumpulan data pada penelitian ini di lakukan dengan cara mencari literatur yang relevan khususnya mengenai penelitian yang telah dilakukan sebelumnya untuk dapat memetakan apa saja yang telah dilakukan peneliti lain sebagai acuan dalam mengembangkan aplikasi. Selanjutnya kajian dokumen di lakukan terhadap dua instrumen yang digunakan untuk melakukan tes yaitu form kertas yang berisi item tes, serta manual pelaksanaan DDST. Hasil kajian dokumen yang dilakukan dijadikan acuan dalam membangun aplikasi, khususnya dalam item soal dan cara menilai. Terakhir wawancara dilakukan terhadap dua narasumber yaitu: Psikolog Anak dari Universitas Islam Indonesia, dan Pakar Pendidikan Anak Berkebutuhan Khusus dari Universitas Negeri Yogyakarta. Hasil wawancara berupa penggunaan alat tes Denver II dan kebutuhan antarmuka yang diharapkan dari aplikasi yang dibangun.

\subsection{Perancangan Aplikasi}

\subsubsection{Usecase Diagram Android}

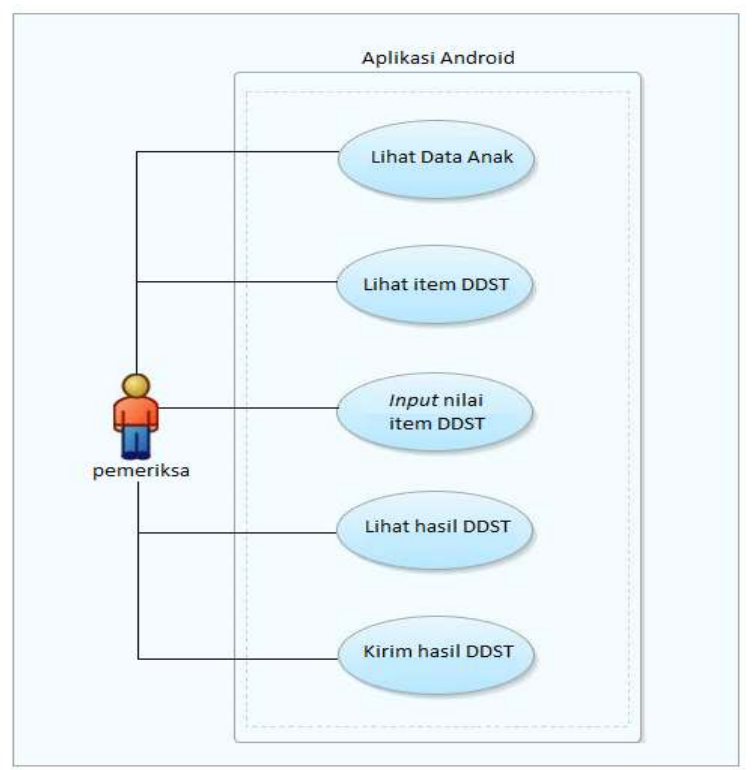

Gambar 2. Usecase Diagram Android.
Gambar 2 merupakan gambaran fungsionalitas sistem pada aplikasi pemeriksa. Berikut penjelasan masing masing fungsionalitas dari sistem pemeriksa.

i. Lihat data anak: Digunakan oleh pemeriksa untuk melihat data anak yang telah atau pernah dimasukkan.

ii. Lihat item DDST : Digunakan oleh pemeriksa ketika melakukan tes untuk melihat item DDST dari masing-masing sektor yang dinilai.

iii. Input nilai item DDST : Digunakan oleh pemeriksa untuk memberi skor dan nilai setiap item hasil tes terhadap anak. Adapaun skor yang dapat diberikan oleh pemeriksa antara lain "P" untuk Pass/Lulus, "F" untuk Fail/Gagal, "NO" untuk No opportunity/Tidak ada kesempatan dan "R" untuk Refusal / Menolak.

iv. Lihat hasil DDST : Digunakan oleh pemeriksa untuk melihat hasil dari tes. Hasil DDST ini akan berisi kesimpulan Normal, Suspek/Dicurigai ada keterlambatan dan Tidak dapat diuji / Untestable.

v. Kirim hasil DDST : Digunakan oleh pemeriksa untuk mengirim hasil tes kepada admin.

\subsubsection{Usecase Diagram Aplikasi Web}

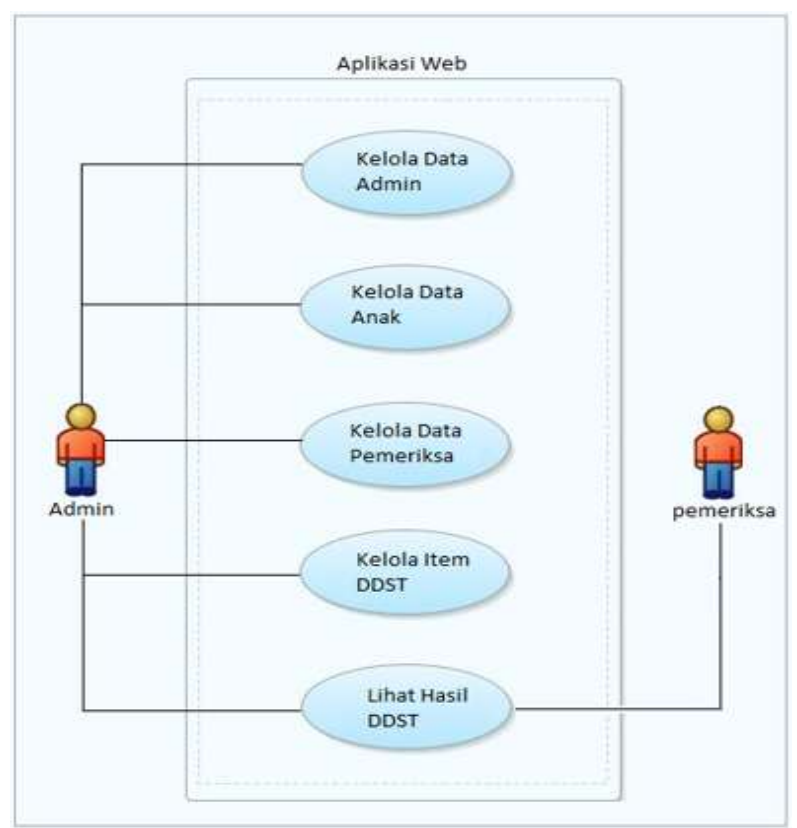

Gambar 3. Usecase Diagram Aplikasi Web. 
Gambar 3 merupakan gambaran funsionalitas sistem pada sistem admin. Berikut penjelasan masing - masing fungsionalitas dari sistem admin dan pemeriksa.

i. Kelola data admin : Fungsionalitas ini digunakan oleh admin untuk menambah, melihat, menghapus, mengubah dan melakukan pencarian data admin.

ii. Kelola data anak : Fungsionalitas ini digunakan oleh admin untuk menambah, melihat, menghapus, mengubah dan melakukan pencarian data anak.

iii. Kelola data pemeriksa: Fungsionalitas ini digunakan oleh admin untuk menambah, melihat, menghapus, mengubah dan melakukan pencarian data pemeriksa.

iv. Kelola item DDST : Fungsionalitas ini digunakan oleh admin untuk mengubah, melihat dan melihat item DDST.

v. Lihat hasil DDST : Digunakan oleh admin dan pemeriksa untuk melihat hasil DDST yang telah dikirim pemeriksa.

\section{HASIL DAN PEMBAHASAN}

\subsection{Hasil}

\subsubsection{Aplikasi Android}

Aplikasi Android digunakan oleh pemeriksa sebagai pengganti form kertas dan manual Denver II.

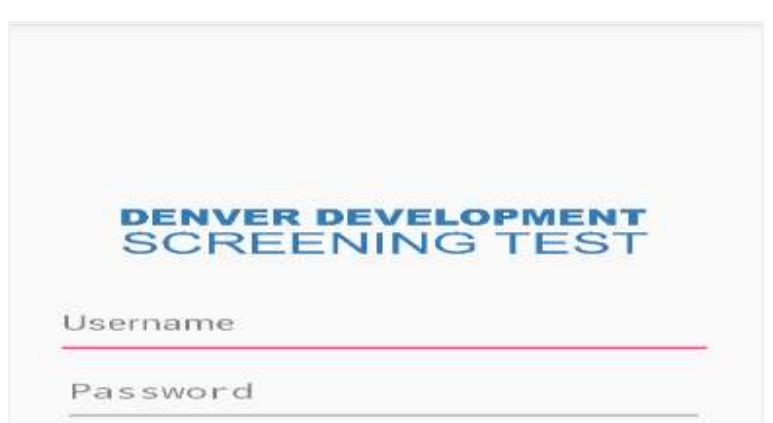

Gambar 4. Halaman Login Pemeriksa.
Gambar 4 menampilkan halaman login pemeriksa, di dalamnya terdapat form username dan password yang harus diisi oleh pemeriksa ketika melakukan asesmen. Username dan password pemeriksa sebelumnya telah terdaftar melalui website administrasi.

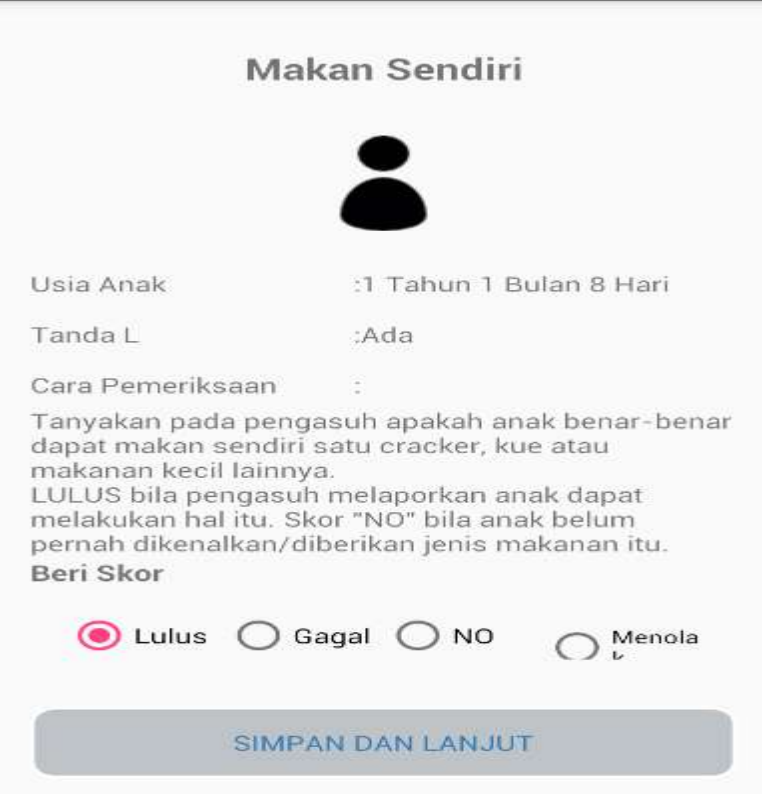

Gambar 5. Halaman Soal.

Gambar 5 menampilkan detail soal masing - masing sektor sesuai umur perkembangan anak. Detail soal yang ditampilkan yaitu :

1. Gambar kondisi lulus pada masingmasing soal, gambar yang dimasukkan merupakan gambar rekomendasi dari psikolog.

2. Umur anak saat asesmen.

3. Tanda L.

4. Cara pemeriksaan.

5. Skor untuk memberikan penilaian terhadap anak.

\subsubsection{Aplikasi $W e b$}

Aplikasi Web digunakan oleh petugas administrasi untuk mengelola data asesmen, dan pemeriksa untuk melihat catatan perkembangan anak. Gambar 6 menampilkan halam login admin, di mana admin harus memasukkan username dan password. Gambar 7 menampilkan hasil 
Tabel 1 Daftar Perangkat Android yang di Gunakan untuk Pengujian

\begin{tabular}{ccccc}
\hline No & Nama Perangkat & Versi Android & Ukuran Layar & RAM \\
\hline 1 & Lenovo A600+ & Lollipop & 5 inch & $2 \mathrm{~GB}$ \\
2 & Tab 3 Samsung SM- & Kitkat & 7 inch & $1 \mathrm{~GB}$ \\
& T211 & & & \\
3 & Samsung Galaxy A5 & Marshmellow & 5.2 inch & $2 \mathrm{~GB}$ \\
4 & Xiaomi Redmi 1S & Jelly Bean & 4.7 inch & $1 \mathrm{~GB}$ \\
\hline
\end{tabular}

asesmen dari anak yang pernah melakukan DST.

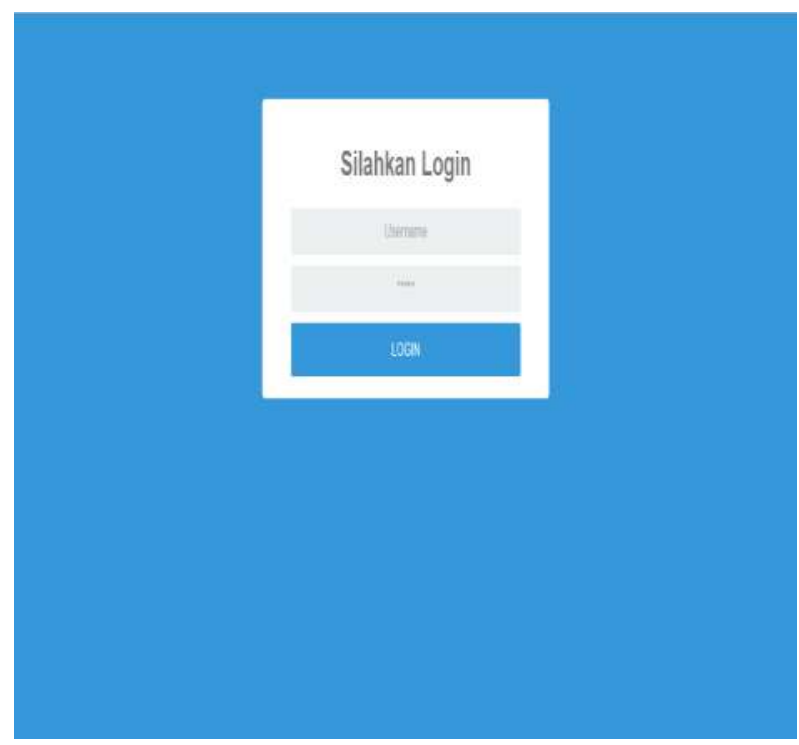

Gambar 6. Halaman Login Admin.

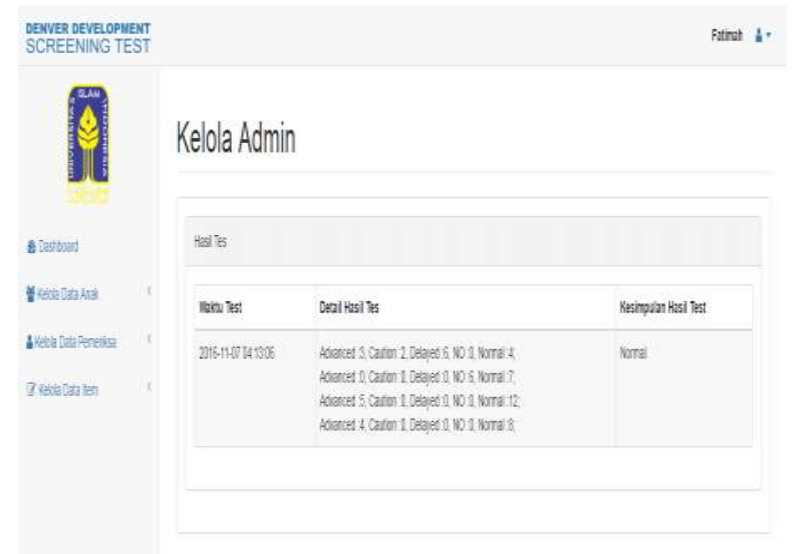

\subsection{Pengujian}

\subsubsection{Pengujian Fungsional}

Pengujian fungsional dilakukan dengan menguji coba aplikasi pada perangkat dengan berbagai spesifikasi dan penilaian pengguna terhadap aplikasi dan sistem.

Tabel 1 menampilkan perangkat yang digunakan dalam pengujian. Terdapat 4 perangkat Android yang digunakan dengan spesifikasi yang berbeda. Hasil pengujian terhadap 4 perangkat Android menunjukkan bahwa aplikasi DDST berbasis Android yang dikembangkan dapat berjalan dengan baik disemua perangkat, layout dan fungsionalitas sistem berjalan dengan baik.

\subsubsection{Skenario Pengujian}

Pengujian dilakukan di dua tempat yaitu: Puskaga (Pusat Studi Anak dan Keluarga) Baiti Janati, jalan Kaliurang km 14,5 Sleman Yogyakarta dan Rumah Sakit Condong Catur, jalan Manggis No.6, Condong Catur, Depok, Sleman. Pengujian dilakukan oleh dua orang pada setiap sesi pengujian. Pengujian di Puskaga melibatkan seorang Psikolog dan seorang mahasiswa program Pascasarjana Profesi Psikolog. Sedangkan pengujian di RS Condong Catur melibatkan seorang Terapis dan mahasiswa Praktek dari Akademi Fisioterapi YAB.

Gambar 7. Halaman Hasil Asesmen. 
Tabel 2 Tabel Data Anak yang di Uji

\begin{tabular}{clll}
\hline $\begin{array}{c}\text { Anak } \\
\text { Ke- }\end{array}$ & \multicolumn{1}{c}{ Usia saat tes } & \multicolumn{1}{c}{ Tanggal Tes } & Jenis Kelamin \\
\hline 1 & 2 tahun, 8 bulan, 13 hari & Rabu, 9 November 2016 & Laki-laki \\
2 & 5 tahun, 25 hari & Senin, 14 November 2016 & Laki-laki \\
3 & 5 tahun, 1 bulan, 21 hari & Rabu, 7 Desember 2016 & Laki-laki \\
4 & 1 tahun, 5 bulan, 16 hari & Rabu, 7 Desember 2016 & Laki-laki \\
5 & 1 tahun, 1 bulan, 29 hari & Selasa, 13 Desember 2016 & Laki-laki \\
6 & 10 bulan, 7 hari & Selasa, 13 Desember 2016 & Laki-laki \\
7 & 1 tahun, 3 bulan, 7 hari & Rabu, 14 Desember 2016 & Laki-laki \\
8 & 7 bulan, 11 hari & Rabu, 14 Desember 2016 & Laki-laki \\
9 & 1 tahun, 1 bulan, 1 hari & Rabu, 14 Desember 2016 & Laki-laki \\
10 & 5 bulan, 18 hari & Rabu, 14 Desember 2016 & Perempuan \\
\hline
\end{tabular}

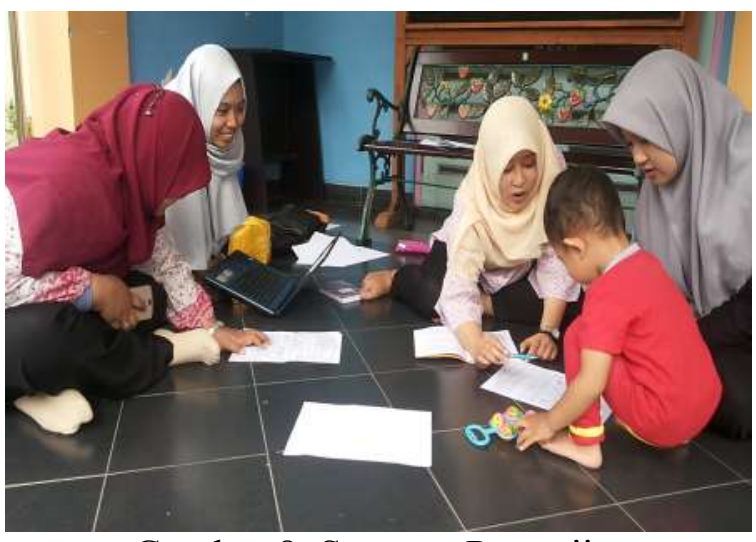

Gambar 8. Suasana Pengujian di Puskaga Baiti Jannati.

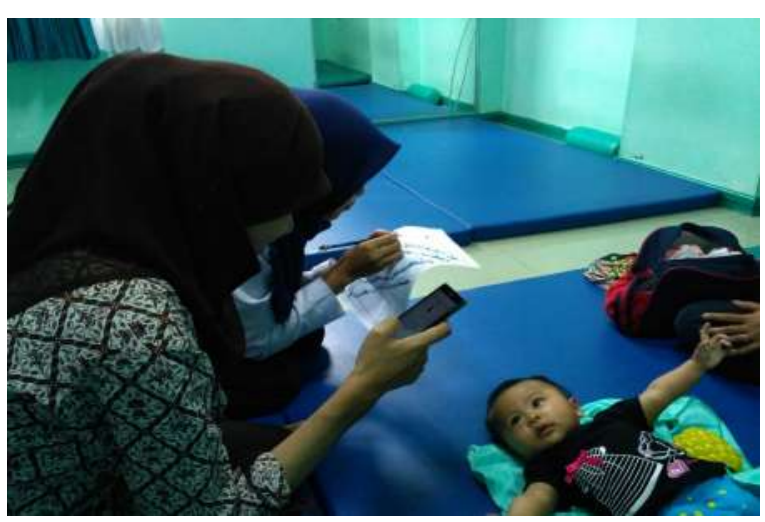

Gambar 9 Suasana Pengujian di Rumah Sakit Condong Catur.

Setiap anak diuji sebanyak satu kali oleh dua pemeriksa secara manual dan menggunakan aplikasi yang telah dikembangkan pada waktu yang bersamaan. Pengujian dilakukan terhadap 10 anak yang terdiri dari 1 perempuan dan 9 laki - laki. Berikut tabel 2 menunjukkan daftar anak yang telah diuji.

\subsubsection{Pengujian Validitas}

Pengujian validitas dilakukan dengan dua metode yaitu Single Decision Threshold dan Koefisien Cohen's Kappa untuk melihat tingkat Sensitifitas, Spesifisitas, dan Total Kinerja Sistem, serta Keeratan Kesepakatan antara hasil pengujian secara manual oleh pemeriksa dengan aplikasi yang dikembangkan.

\section{a. Single Decision Threshold}

Single Decision Threshold dilakukan dengan menentukan 4 kemungkinan keputusan, yaitu :

1. TP (True Positive), dimana hasil pengujian baik secara manual maupun aplikasi menyatakan Normal.

2. FP (False Positive), dimana hasil pengujian secara manual menyatakan suspek namun aplikasi menyatakan normal.

3. FN (False Negative), dimana hasil pengujian secara manual menyatakan normal namun aplikasi menyatakan suspek.

4. TN (True Negative), dimana hasil pengujian baik secara manual maupun aplikasi menyatakan Suspek.

Tabel 3 menunjukkan hasil pengujian terhadap anak di Puskaga Baiti Jannati dan Rumah Sakit Condong Catur. 
Tabel 3 Hasil Pengujian

\begin{tabular}{cccc}
\hline No & $\begin{array}{c}\text { Hasil Uji } \\
\text { Aplikasi }\end{array}$ & $\begin{array}{c}\text { Hasil Uji } \\
\text { Manual }\end{array}$ & $\begin{array}{c}\text { Kesesuai } \\
\text { an }\end{array}$ \\
\hline 1 & Suspek & Suspek & Ya \\
2 & Normal & Normal & Ya \\
3 & Suspek & Suspek & Ya \\
4 & Suspek & Suspek & Ya \\
5 & Suspek & Suspek & Ya \\
6 & Suspek & Suspek & Ya \\
7 & Suspek & Suspek & Ya \\
8 & Normal & Suspek & Tidak \\
9 & Suspek & Suspek & Ya \\
10 & Normal & Normal & Ya \\
\hline
\end{tabular}

Nilai sensitifitas dan spesifisitas dari hasil pengujian didapatkan melalui persamaan berikut.

$$
\begin{aligned}
& \text { Sensitifitas }=\frac{T P}{T P+F N} \times 100 \% . \\
& \text { Spesifisitas }=\frac{T N}{F P+T N} \times 100 \% .
\end{aligned}
$$

Total kinerja sistem, didapatkan melalui persamaan berikut.

$$
\frac{T N+T P}{T N+T P+F N+F P} \times 100 \%
$$

Pengujian yang telah dilakukan menunjukkan tingkat sensitivity aplikasi sebesar $100 \%$, specificity sebesar $87.5 \%$ dan nilai kinerja aplikasi sebesar $90 \%$. Perbedaan keputusan yang terjadi pada kasus ke- 8 pada tabel 4.2 lebih kepada perbedaan secara subjektif pemeriksa. Dimana pemeriksa lebih meyakini hasil penilaian terhadap anak ke-8 lebih mengarah kepada normal, meskipun perhitungan menunjukkan suspek.

\section{b. Koefisien Cohen's Kappa}

Nilai Keeratan Kesepakatan antara hasil pengujian secara manual oleh pemeriksa dengan aplikasi yang dikembangkan didapat melalui persamaan, Tabel 4 menampilkan hasil akhir tes DDST.

$k=\frac{\operatorname{pr}(a)-\operatorname{pr}(a)}{1-\operatorname{pr}(e)}$
$\operatorname{Pr}(\mathrm{a})=$ Persentase jumlah pengukuran yang konsisten antar rater.

$\operatorname{Pr}(\mathrm{e})=$ Persentase jumlah perubahan pengukuran antar rater.

Tabel 4. Tabel Hasil Pengujian

\begin{tabular}{lccccc}
\hline & & \multicolumn{3}{c}{ Aplikasi DDST } & \\
\cline { 3 - 5 } & & $\begin{array}{c}\text { Nor } \\
\text { mal }\end{array}$ & $\begin{array}{c}\text { Su } \\
\text { sp } \\
\text { ek }\end{array}$ & $\begin{array}{c}\text { Tidak } \\
\text { dapat } \\
\text { diui }\end{array}$ & Total \\
\hline $\mathrm{M}$ & Normal & 2 & 0 & 0 & 2 \\
$\mathrm{a}$ & $\begin{array}{c}\text { Suspek } \\
\mathrm{n}\end{array}$ & 1 & 7 & 0 & 8 \\
$\mathrm{u}$ & $\begin{array}{c}\text { Tidak } \\
\text { dapat }\end{array}$ & 0 & 0 & 0 & 0 \\
$\mathrm{a}$ & diuji & & & & \\
$\mathrm{l}$ & Total & 3 & 7 & 0 & 10 \\
\hline
\end{tabular}

Dimana,

$\operatorname{Pr}(a)=\frac{2+7+0}{10}=0.9$

Hasil pengukuran Normal menggunakan

Aplikasi : $\frac{2+\mathbf{1}+0}{10}=0.3$

Manual : $\quad \frac{2+0+0}{10}=0.2$

Hasil pengukuran Suspek menggunakan :

Aplikasi : $\frac{0+7+0}{10}=0.7$

Manual : $\frac{1+7+0}{10}=0.8$

Hasil pengukuran Untestable menggunakan:

Aplikasi : $\frac{0+0+0}{10}=0$

Manual : $\quad \frac{0+0+0}{10}=0$

Perubahan kemungkinan hasil pengukuran :

Normal : $\quad 0.3 \times 0.2=0.06$

Suspek: $0.7 \times 0.8=0.56$

Untestable : $0 \times 0=0$ 
Total hasil pengukuran antar rater :

$\operatorname{Pr}(e)=0.06+0.56+0=0.62$

Nilai Koefisien Cohen’s Kappa

$k=\frac{0.9-0.62}{1-0.62}=0.74$

Berdasarkan tabel 5 interpretasi Cohen's Kappa sebagai berikut:

Tabel 5 Keeratan Kesepakatan

\begin{tabular}{cc}
\hline Nilai Kappa & $\begin{array}{c}\text { Keeratan } \\
\text { Kesepakatan }\end{array}$ \\
\hline $0.00-0.20$ & Sangat Rendah \\
$0.21-0.40$ & Rendah \\
$0.41-0.60$ & Cukup \\
$0.61-0.80$ & Kuat \\
$0.81-1.00$ & Sangat Kuat \\
\hline
\end{tabular}

Maka, dengan nilai Kappa 0.74 aplikasi memiliki nilai keeratan kesepakatan Kuat.

\subsubsection{Pengujian Usabilitas}

Pengujian usabilitas dilakukan dengan cara melakukan wawancara terhadap 2 orang Psikolog dari Universitas Islam Indonesia dan seorang Pakar Pendidikan Anak Berkebutuhan Khusus dari Universitas Negeri Yogyakarta. Dari hasil wawancara yang dilakukan meninjukkan bahwa sistem yang dikembangkan dianggap sangat baik dan dapat membantu pemeriksa saat proses asesmen. Beberapa masukan mengenai penelitian kedepan antara lain: perlunya diujikan pada jumlah anak yang lebih banyak dengan jumlah pemeriksa dengan latarbelakang yang lebih beragam untuk melihat keakuratan hasil, serta pada aplikasi berbasis web dapat dikembangkan fitur untuk pakar yang dapat digunakan untuk berkolaborasi antar pakar dalam melakukan asesmen pada perkembangan anak. Gambar 9 menunjukkan suasana wawancara dengan pakar.

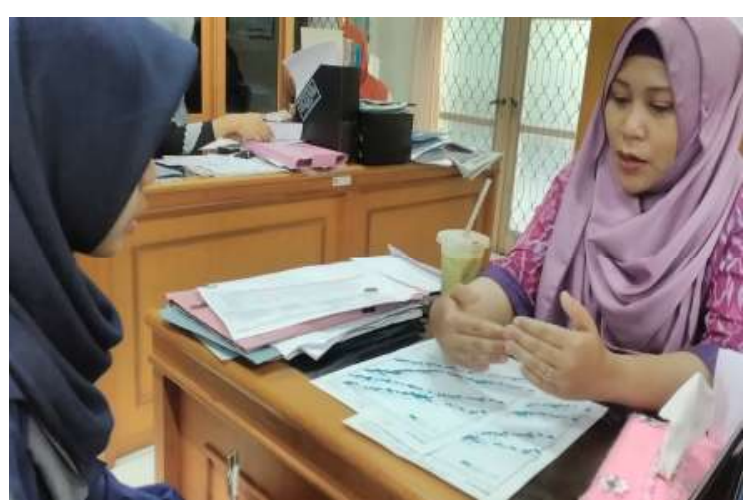

Gambar 9. Suasana Wawancara dengan Pakar.

\section{KESIMPULAN}

Aplikasi Denver Development Screening Test (DDST) telah diuji di Puskaga Baiti Janati dan Rumah Sakit Condong Catur. Hasil pengujian validitas yang dilakukan menggunakan metode Single Decision Thesrhold menunjukkan nilai sensitifitas aplikasi sebesar $100 \%$, spesifisitas sebesar $87.5 \%$ dan nilai kinerja aplikasi sebesar 90\%,. Selanjutnya hasil pengujian dengan metode Koefisien Cohen's Kappa menunjukkan nilai interpretasi Kuat yaitu sebesar 0.74 .

\section{DAFTAR PUSTAKA}

Frankenburg, W. K., Dodds, J., Archer, P., Shapiro, H., \& Bresnick, B. The Denver II: a major revision and restandardization of the Denver Developmental Screening Test. Pediatrics, 89(1), 91-97, 1992.

Frankenburg, W. K., \& Dodds, J. B. The Denver developmental screening test. The Journal of Pediatrics, 71(2), 181191, 1967.

Gumiri, V. L., Puspitaningrum, D., \& Ernawati, E. Sistem Pakar Klasifikasi Status Perkembangan Anak Usia Dini Dengan Metode Naïve Bayes Classifer Berbasis DDST Rules. Rekursif, 3(2), 107-122, 2015. 
Ivantoni, R., \& Muhimmah, I. Aplikasi Penentuan Tingkat Tumbuh Kembang Anak Menggunakan Tes Denver II. In Seminar Nasional Informatika Medis (SNIMed) (pp. 124-132), 2015.

Laksana, T. G., \& Sriyulia, E. Diagnosis Kebutuhan Gizi pada Balita Melalui Penerapan Sistem Pakar Menggunakan Metode Certainty Factor. In Prosiding SNST Fakultas Teknik (pp. 13-18), 2016.

Nugroho, H. S. W. Denver Developmental Screening Test: Petunjuk Praktis. (E. A. Mardella, Ed.). Jakarta: Penerbit Buku Kedokteran EGC, 2008.

Pilllitteri, A. Maternal \& Child Health Nursing: Care of the Childbearing \& Childbearing Family (6th ed.). The Point, 2010.

Widodo, D. W., Kusrini, \& Boedijanto, E. Perancangan Sistem Pakar Deteksi Dini Tumbuh Kembang Anak Berbasis Multimedia. SISFOTENIKA, 4(2), 128139, 2014. 